\title{
Bērnu tiesības uz materiālo nodrošinājumu: tiesiskais regulējums un piedziņas problemātika
}

\author{
Mg. iur., Mg. paed. Sanita Vanaga \\ Rìgas Stradiṇa universitāte, Juridiskā fakultāte, Latvija \\ vanagusanita@gmail.com
}

\section{Kopsavilkums}

Bērnu tiesības uz materiālo nodrošinājumu ir būtiska un neatṇemama cilvēktiesību sastāvdaḷa, kas nostiprināta kā nacionālajos, tā arī starptautiskajos tiesību aktos. Šajā rakstā tiek analizēta bērna materiālo vajadzību nodrošināšanai nepieciešamo uzturlìdzekḷ u būtība un apjoms atkarībā no bērna juridiskā statusa un skaidrota bērna juridiskā statusa tiesiskā nozīme. Publikācijā atspoguḷota valsts un pašvaldību izveidotā atbalsta koncepcija, nodrošinot bērniem uzturlīdzekḷ us materiālo vajadzību nodrošināšanai, kā arī problemātika, kas saistīta ar uzturlīdzekḷu pierādīšanu un to piedziṇu tiesvedības procesā.

Atslēgvārdi: bērnu tiesības, materiālais nodrošinājums, uzturlīdzekḷi.

\section{levads}

Bērnu tiesības ir tieši saistāmas ar cilvēktiesībām, tām raksturīgs specifisku iezīmju kopums, kas izpaužas gan bērnu ikdienas aprūpē, gan viṇu labklājības, vides un materiālā ieguldījuma nodrošināšanā. Bērna materiālo vajadzību nodrošināšana ir viens no pamatnoteikumiem, lai bērns attīstītos par pilnvērtīgu sabiedrības locekli un kḷūtu par sabiedrības nākotnes pamatu. Šo vajadzību nodrošināšana ir cieši saistìta ar bērna juridisko statusu un valsts un pašvaldību koncepciju, nosakot uzturlīdzekḷu apmēru materiālo vajadzību garantēšanai.

Latvijā tiek piemēroti daudzi tiesību akti, piemēram, Latvijas Republikas Satversme, Civillikums, Bērnu tiesību aizsardzības likums u. c., kuros nostiprinātas cilvēka pamattiesības. Tie regulē arī bērnu tiesību ievērošanu - tiesības uz aprūpi un audzināšanu, labvēlīgiem sadzīves apstākḷiem un sociālo vidi, par ko galvenokārt atbildīgi ir bērnu likumiskie pārstāvji - vecāki. Lai tiktu ievēroti visi priekšnosacījumi un tiesību aktos 
noteiktās bērnu tiesības un intereses, būtiska nozīme ir bērna vecāku materiālajam ieguldījumam, gādājot ne tikai par bērna pamatvajadzībām, bet arī tām, kuras ir saistītas ar bērna personības izaugsmi un spēju pilnvērtīgi attīstìties.

Valsts bērnu tiesību aizsardzības inspekcijas apkopotie statistikas dati par 2017. gadā ārpusğimenes aprūpē nonākušajiem 6669 bērniem liecina, ka vecāku spēja un izpratne par bērnu tiesību nodrošināšanu ir nepietiekama. Tādēl tiek piemērots ìpašs mehānisms: tiek noteikts likumiskais bērna pārstāvis, kurš turpmāk pārstāvēs vina tiesības un intereses ne tikai ikdienā, bet arī tiesiskā ceḷā, lai bērns saṇemtu pilnvērtīgu materiālo nodrošinājumu pozitīvai savas personības izaugsmei, kḷūstot par pilnvērtīgu sabiedrības locekli [36].

Šì brīža tiesiskajā regulējumā paredzēts, ka bērna aprūpe jāisteno Civillikuma 177. panta izpratnē, t. i., vecākiem ir visi no aizgādības tiesībām izrietošie pienākumi attiecībā uz vinuu nepilngadīgo bērnu, savukārt 179. pantā ir noteikts, ka pienākums uzturēt bērnu gulstas uz abiem vecākiem līdz laikam, kad bērns pats sevi spēj apgādāt. Turklāt vecāku uztura došanas pienākums neizbeidzas, ja bērns ir šḳirts no giimenes vai nedzīvo kopā ar vienu no vecākiem [3].

Rakstā analizētās tiesību normas, statistikas un pētījumos iegūtie dati liecina par problēmu kopumu, kas saistīts ar vispārēju sabiedrības izpratnes trūkumu par bērnam nepieciešamo materiālo nodrošinājumu, un tiesību normu neprecizitātēm.

Raksta mērkisis ir sniegt tiesiskā regulējuma skaidrojumu par bērna materiālo vajadzību nodrošināšanu, kam nepieciešams noteikts uzturlīdzekḷ apmērs, un norādìt uz problēmām, kas saistītas ar uzturlīdzekḷ u apmēra pierādīšanu un piedziṇu tiesvedības procesā, kā arī aktualizēt bērna juridiskā statusa skaidrojumu.

\section{Materiāls un metodes}

Raksts sagatavots, balstoties uz pētījumu, kurā izmantotas vispārējās zinātniskās pētniecības metodes (salīdzinājuma metode, lai analizētu tiesību normas, definīcijas un ikdienas praksi; analizzes un sintēzes metode - atsevišḳu secinājumu un priekšlikumu izteikšanai; kvantitatīvā metode, ar ko iegūti pētījuma dati) un tiesību normu interpretācijas metodes (gramatiskā metode - log̣iskā interpretācijas metode, ar ko skaidrota rakstā iekḷauto tiesību normu jēga; sistēmiskās interpretācijas metode, ar ko skaidrota tiesību normu izpēte un analīze kontekstā ar citām tiesību normām; vēsturiskās interpretācijas metode, norādot likumdevēja gribu, ieviešot konkrēto tiesību normu; teleoloǵiskās interpretācijas metode, kura izmantota, lai skaidrotu publikācijā iekḷauto tiesību aktu veidu un mērḳi, kā arī mērḳi, kas būtu jāsasniedz). 
Sanita Vanaga. Bērnu tiesības uz materiālo nodrošinājumu:

tiesiskais regulējums un piedziṇas problemātika

\section{Bērna materiālās vajadzības un to nodrošināšanai nepieciešamo uzturlīdzekḷu apjoma tiesiskais regulējums}

Civillikuma 219. panta izpratnē bērns ir nepilngadīga persona, kura vēl nav sasniegusi astoṇpadsmit gadu vecumu. Saskaṇā ar Civillikuma 177. panta pirmo un otro dalıu, 178. panta pirmo dalı atbildība un rūpes par bērnam nepieciešamo vajadzỉbu nodrošināšanu jāuzṇemas vecākiem, kas ir bērna dabiskie aizbildṇi, savukārt bērna aprūpe tiek definēta kā vecāku aizgādības tiesības un pienākumi pret viṇu nepilngadīgo bērnu [3]. Analizējot bērnu dabisko un likumisko aizbildṇu un aprūpētāju izpratni par bērnam nepieciešamo materiālo vajadzību nodrošinājumu, secināms, ka tā ir krasi atšḳirīga un neviennozīmīga. To apliecina Valsts bērnu tiesību aizsardzības inspekcijas ikgadējo gadu pārskatu par bāriṇtiesu darbu kopsavilkuma statistikas dati [37] un šajā pētījumā veiktās aptaujas par bērnam nepieciešamo materiālo nodrošinājumu datu analīze.

Šì brīža tiesiskajā regulējumā nav iekḷauta skaidra un nepārprotama uzturlīdzekḷu definīcija, tomēr bērna aprūpes nodrošināšanā ikviena vecāka pienākums ir vadīties pēc Civillikuma 177. panta bērna aprūpes definējuma: vecāka pienākums ir nodrošināt bērna aprūpi, kas ietver apgādāšanu ar ēdienu, apgeērbu, mājokli, veselības uzturēšanu, bērna kopšanu, izglïtošanu un audzināšanu, bērna uzraudzību, kas ietver bērna drošību un trešās personas apdraudējuma novēršanu, kā arī bērna dzīvesvietas nodrošināšanu un rūpes par bērna mantu [3]. Bērna ikdienas vajadzībām nepieciešamais materiālais nodrošinājums tiek skaidrots kā materiālā palīdzība (angḷu val. material, financial aid), kas definēta kā naudas izmaksas un mantiski pabalsti [31, 461; 32, 265], kas jāvērtē kontekstā ar uzturlīdzekḷu jēdziena definējumu, ka "tēvam un mātei samērā ar viṇu mantas stāvokli ir pienākums apgādāt bērnus līdz laikam, kad viṇi paši varēs sevi apgādāt [..]” [32, 185].

Uzturlïdzekḷu garantiju fonda likumā noteikts, ka uzturlīdzekḷi ir "bērna ikmēneša uzturēšanas izdevumi, kurus nodrošināt bērnam ir katra vecāka pienākums neatkarīgi no viṇa spējām uzturēt bērnu un viṇa mantas stāvokḷa un kuru minimālo apmēru, pamatojoties uz Civillikuma 179. panta piekto daḷu, noteicis Ministru kabinets" [16]. Tātad bērna materiālais nodrošinājums un uzturlīdzekḷi ir savstarpēji saistīti jēdzieni, taču nevienā no tiesību aktiem vai piedāvātajiem definējumiem nav skaidri un nepārprotami noteikts, kādas tieši ir bērna materiālās vajadzības, kuru nodrošināšanai nepieciešams noteikts uzturlīdzekḷ apjoms.

Neatkarīgi no katra vecāka labklājības līmeṇa, mantiskā stāvokḷa un spējām materiāli gādāt par bērnu, kā tas paredzēts Civillikuma 179. panta piektajā dạ̦ā [3], 15.01.2013. Ministru kabineta noteikumos Nr. 37 "Noteikumi par minimālo uzturlīdzekḷu apmēru bērnam" (turpmāk tekstā - MK noteikumi Nr. 37) reglamentēta uzturlīdzekḷu aprēḳina kārtỉba bērniem līdz septiṇu gadu vecumam un no septinu lìdz 18 gadu vecumam. Tas nozīmē, ka bērnam līdz septiṇu gadu vecumam uzturlīdzekḷi tiek aprēḳināti $25 \%$ apmērā no Ministru kabineta noteiktās minimālās mēneša darba algas un bērnam no septinu gadu vecuma līdz 18 gadu vecumam - 30 \% apmērā [11]. Tātad 2019. gadā, tāpat kā 2018. gadā, saglabājoties minimālajai mēneša darba algai normālā darba laika ietvaros 
430 eiro apmērā, katram bērnam ir tiesības saṇemt ne mazāk kā minimālo materiālo nodrošinājumu 107,50 eiro apmērā līdz septiṇu gadu vecumam un 129 eiro apmērā no septiṇu lìdz 18 gadu vecuma sasniegšanai.

Šis procentuālais iedalījums tiesiskajā regulējumā, nosakot minimālo uzturlīdzekḷ apmēru bērnam materiālā nodrošinājuma segšanai, vēsturiski ar ìpašu uzdevumu ministra bērnu un ǵimenes lietās sekretariāta publikāciju "Par uzturlīdzekḷu apmēru bērnam" tika skaidrots oficiālajā laikrakstā "Latvijas Vēstnesis", norādot, ka "Ministru kabineta noteikumu [..] mērḳis ir atbilstoši spēkā esošajām tiesību aktu normām noteikt minimālo uzturlīdzekḷu apmēru, kādu nodrošināt bērnam ir pienākums katram no vecākiem neatkarīgi no viṇa mantas stāvokḷa. Minimālais uzturlīdzekḷu apmērs, kādu katram no vecākiem ir pienākums katru mēnesi nodrošināt katram savam bērnam no viṇa piedzimšanas briža līdz septiṇu gadu vecuma sasniegšanai, tiek noteikts 25 \% apmērā no valstī noteiktās minimālās mēneša darba algas. Savukārt minimālais uzturlīdzekḷ apjoms, kuru katram no vecākiem ir pienākums katru mēnesi nodrošināt bērnam no septiṇu gadu vecuma sasniegšanas dienas līdz 18 gadu vecuma sasniegšanai, tiek noteikts 30 \% apmērā no valstĩ noteiktās minimālās mēneša darba algas, jo skolas vecuma bērnu uzturēšanai sakarā ar izdevumiem mācību līdzekḷu un mācību procesam nepieciešamā inventāra iegādei ir vajadzīgi lielāki līdzekḷi." Šāds skaidrojums tika sniegts, pamatojoties uz 01.07.2003. apstiprinātajiem Ministru kabineta noteikumiem Nr. 348 "Noteikumi par minimālo uzturlīdzekḷu apmēru bērnam”, kuri 01.01.2013. zaudēja spēku. Pien̦emot MK noteikumus Nr. 37, šis procentuālais minimālo uzturlìdzekḷu apmērs tika saglabāts un detalizētāks skaidrojums par izvirzìto procentuālo iedalījumu netika sniegts, nosakot minimālo uzturlīdzekḷ apmēru bērna materiālo vajadzību nodrošināšanai. [34]

Civillikuma tiesību normās paredzētas bērna dabisko un likumisko pārstāvju tiesības un pienākumi, īstenojot bērna aprūpi un nodrošinot viņa materiālās vajadzības, savukārt MK noteikumos Nr. 37 - uzturlīdzekḷu minimālā apjoma izmaksas bērna materiālo vajadzību segšanai lïdz bērna 18 gadu vecuma sasniegšanai.

Tomēr jāuzsver, ka šie tiesību akti neizšḳir materiālā nodrošinājuma saṇemšanu bērnam atkarībā no viṇa juridiskā statusa, jo tiesības saṇemt minimālo uzturlīdzekḷu apmēru ir katram bērnam. Savukārt bērnam, atrodoties ārpusǵimenes aprūpē, tiek piemērotas speciālās tiesību normas, nosakot valsts un pašvaldību pienākumu sniegt atbalstu bērnu materiālajam nodrošinājumam ārpusğimenes aprūpē nonākušiem bērniem. Šā atbalsta sniegšanas kārtība noteikta vairākos tiesību aktos, piemēram, Valsts sociālo pabalstu likumā [17], 22.12.2009. Ministru kabineta noteikumos Nr. 1643 "Kārtība, kādā piešķir un izmaksā pabalstu aizbildnim par bērna uzturēšanu" [8] u. c. Šajos tiesību aktos paredzēta bērna pamatvajadzību nodrošināšana minimālā apjomā, tiesiskais regulējums nenosaka apmēru, līdz kuram uzturlīdzekḷu summa drīkst būt palielināta. Šāda dispozīcija ir veidojusies tāpēc, ka nevienā nacionālajā tiesību aktā nav noteikts konkrēts materiālā nodrošinājuma jeb uzturlīdzekḷu definējums, kas nepārprotami ḷautu saprast, kas tieši uzturlīdzekḷos tiek ietverts. 
Sanita Vanaga. Bērnu tiesības uz materiālo nodrošinājumu: tiesiskais regulējums un piedziṇas problemātika

Vienlaikus jāatzīmē, ka neviens tiesību akts, kurā noteikta uzturlīdzekḷu aprēkịināšanas kārtība, nav balstīts uz bērnam nepieciešamo preču un pakalpojumu pārtikas grozu. Latvijas Zinātṇu akadēmijas akadēmiḳis Oḷgerts Krastiṇ̌š ir norādījis, ka saskaṇā ar definīciju iztikas minimums ir preču un pakalpojumu grozs un to apjoms, kas cilvēkam nodrošina minimālo iztikas līmeni [30]. Šajā gadijjumā jāatzīmē, ka pirmais iztikas minimuma patēriña preču un pakalpojumu grozs tika noteikts 1991. gadā, pamatojoties uz Ministru Padomes 08.04.1991. lēmumu Nr. 95, kas šobrīd ir zaudējis spēku [13]. Šajā lēmumā noteiktais iztikas minimuma grozs pastāvēja 23 gadus, tomēr kopš 1996. gada praksē tas netika ṇemts vērā un to izmantoja tikai statistikas nolūkos [29]. Savukārt saskaṇā ar Centrālās statistikas pārvaldes sniegto informāciju pilna iztikas minimuma preču un pakalpojumu groza vērtība netiek aprēḳināta no 2014. gada [41].

Tāpēc var secināt, ka šobrīd tiesiskajā regulējumā nepastāv iztikas minimuma patēriņa preču un pakalpojumu grozs (tā izstrāde šobrīd notiek Labklājības ministrijā), kas vienlaikus nozīmē, ka nav arī skaidri definēts, cik liels ir bērna ikdienas pamatvajadzību apjoms, bet uzturlīdzekḷu apjoms bērna materiālajam nodrošinājumam tiek noteikts, interpretējot Civillikuma 177. pantā noteikto bērna aprūpes definējumu.

Bērna materiālās vajadzības un to apjomu šì briža tiesiskais regulējums l̦auj brīvi interpretēt, tāpēc termins "materiālais nodrošinājums" jāiedala divās daḷās, saistot tās ar noteiktu naudas līdzekḷ summu un konkrētām materiālajām vērtībām, piemēram, bērna apgeērbu, nepieciešamo pārtiku, tai skaitā specializēto pārtiku, izglìīibas iegūšanu un ārpusskolas aktivitāšu nodrošināšanu. Savukārt uzturlīdzekḷi ir naudas līdzekḷi, noteikta summa, lai nodrošinātu bērna materiālās vajadzības. Iekḷaujot materiālā nodrošinājuma definējumu tiesību aktos, tas skaidri pozicionētu ikviena bērna vajadzību apjomu, mazinātu izmaksājamo uzturlīdzekḷ apjoma starpību, kas rodas atkarībā no bērna juridiskā statusa, kā arī mazinātu uzturlīdzekḷu pierādīšanas problēmas tiesvedības procesā.

Saseksas Eiropas institūta Saseksas cilvēktiesību pētījumu centra tiesību zinātṇu profesors Nuno Fereira (Nuno Ferreira) ir pētïis bērnu tiesību integrēšanu ES dalïbvalstu tiesību sistēmā saistībā ar dalībvalstu līgumos iekḷautiem noteikumiem un valsts politiku civillietās, tuvinot ES dalībvalstu tiesību aktus vienotai normu ievērošanai. Fereira norādījis, ka bērnu tiesību iekḷaušana tiesību aktos un to ievērošana ir neizbēgama, tomēr vienlaikus arī apdraudēta, kaut arī tikai netieši. Bieži bērnu tiesības netiek īpaši uzsvērtas, pietiekami izdebatētas un saskaņotas pirms to iekḷaušanas tiesību normās, tās paliek vispārējā līmenī un nerada pienācīgas sekas attiecībā uz konkrētiem tiesību elementiem.

Galvenokārt bērnu tiesību kā vienotas normas iekḷaušana tiesību aktos ir attiecināma uz vienu un to pašu mērḳi, t. i., lai nodrošinātu bērnu tiesību ievērošanu un garantētu līdzīgus problēmu risinājumus visās ES dalībvalstīs. Iekḷaujot bērnu pamattiesības tiesību aktos, galvenais mērḳis ir neatstāt bērnu tiesības neaizsargātas. Savukārt šāda vienota izpratne par bērnu tiesību iekḷaušanu tiesību aktos, kas būtu attiecināma uz visām ES dalībvalstīm, ir sarežǵìts process, kas saistīts ar katras valsts politisko saprātīgumu, leǵitimitāti, mērḳiem un izvirzītajiem pienākumiem attiecībā pret jebkuru juridisku lietu, to skaitā bērnu tiesībām un valsts redzējumu bērnu tiesību nodrošināšanā nākotnē. Tas 
nozīmē katras valsts spēju atteikties no esošajiem tiesību aktiem par labu kopējiem ES dalïbvalstu tiesību aktiem. Faktiski katras ES dalībvalsts tiesību akti, kuri ietver bērnu tiesības, atspoguḷ šis valsts sociālos un morālos uzskatus un saistību uzṇemšanos, nodrošinot bērnu tiesības un bērnu attiecību veidošanos ar gimeni. Lai sasniegtu ekonomisko un sociālo taisnīgumu, bērnu tiesībām jāpievērš ìpaša uzmanība, tām jābūt saskaṇotām un tās pienācīgi jāṇem vērā visās ES iestādēs [26, 571-594].

Profesora Fereiras norādītās problēmas ar bērnu tiesību iekḷaušanu tiesību aktos ir saskatāmas arī nacionālā līmenì. Piemēram, Latvijā šì brīža tiesiskais regulējums ne tikai neietver uzturlīdzekḷu definīciju, bet arī nesatur detalizētu skaidrojumu par MK noteikumos Nr. 37 iekḷauto noteikto uzturlïdzekḷ u apmēra procentuālo skaidrojumu, savukārt tam ir saistoši vairāki šeit minētie tiesību akti, uz kuru pamata tiek noteikts pabalstu lielums bērna materiālo vajadzību nodrošināšanai. Tādēl nav piel̦aujams šāds tiesiskais regulējums, uz kuru tiek balstìta bērnu tiesību nodrošināšana.

\section{Bērna juridiskais statuss un valsts un pašvaldību sniegtais atbalsts bērna materiālajam nodrošinājumam}

Latvijas Republikas Satversmes 89. pantā garantēta Latvijas iedzīvotāju pamattiesỉbu nodrošināšana, ar tām saprotot arī bērnu pamattiesības [9], savukārt detalizēts bērnu pamattiesību skaidrojums dots Bērnu tiesību aizsardzības likuma tiesību normās [2] un starptautiskajos dokumentos, kuros uzsvērts, ka bērni nav spējīgi paši sevi aizsargāt, tāpēc bērnu aizsardzībai jāpievērš īpaša uzmanība. Viens no starptautiskiem bērnu tiesību aizsardzības dokumentiem ir Bērnu tiesību konvencija, kura Latvijai ir saistoša kopš 1992. gada 14. aprīla [1]. Svarīgākie starptautiskie tiesību dokumenti bērnu tiesību jomā ir izstrādāti starptautisko cilvēktiesību un starptautisko humanitāro tiesību ietvaros, tomēr tajos nav paredzēta daudzu bērnu tiesībām būtisku jautājumu, piemēram, bērna juridiskā statusa maiṇas, regulēšana $[25,409]$.

Nevienā nacionālajā tiesību aktā nav bērna juridiskā statusa definējuma. Tas skaidrojams ar bērnam noteikto aprūpes formu. Latvijā bērnam ir noteikta gimenes vai ārpusgimenes aprūpes forma, kuras juridiskais statuss saistāms ar aprūpes formai noteikto likumisko pārstāvi. G̦imenes aprūpē tie ir bērna dabiskie aizbildṇi - vecāki -, savukārt, ievietojot bērnu ārpusğimenes aprūpē, bērnam tiek iecelts likumiskais aizbildnis. Nodibinot bērnam ārpusğimenes aprūpi un aizbildnību, par likumisko pārstāvi kḹūt aizbildnis, audžuğimenē ievietota bērna likumiskais pārstāvis ir bāriṇtiesa kā institūcija un trešā persona, savukārt, ievietojot bērnu ilgstošas sociālās aprūpes un sociālās rehabilitācijas institūcijā, par bērna likumisko pārstāvi kḷūst šìs institūcijas vadītājs, kuram piešķirtas no tiesību normām izrietošās aizbildṇa tiesības un pienākumi.

Bērnu pamattiesību ievērošanu pastiprina Bērnu tiesību konvencijas pirmās dalıas 27. pantā teiktais: "Dalībvalstis atzīst ikviena bērna tiesības uz tādu dzīves līmeni, kāds nepieciešams bērna fiziskai, intelektuālai, garīgai, tikumiskai un sociālai attīstībai. Vecāki vai viens no viniiem, vai citas par bērnu atbildīgas personas ir galvenie atbildīgie par bērna 
Sanita Vanaga. Bērnu tiesības uz materiālo nodrošinājumu:

tiesiskais regulējums un piedziṇas problemātika

attīstībai nepieciešamo dzives apstākḷu nodrošināšanu savu spēju un finansiālo iespēju robežās. Dalībvalstis saskañā ar saviem apstākḷiem un iespējām veic attiecīgus pasākumus, lai sniegtu palīdzību vecākiem un citām par bērnu atbildīgām personām šo tiesību īstenošanā, un vajadzības gadījumā nodrošina materiālo palīdzību un atbalsta programmas, īpaši attiecībā uz uzturu, apgeērbu un mājokli. Dalïbvalstis veic visus attiecīgos pasākumus, lai nodrošinātu uzturlīdzekḷ u piedziṇu no vecākiem vai citām personām, kas ir finansiāli atbildīgas par bērnu, gan pašā dalībvalstī, gan arī no ārvalstīm. İpaši tad, ja persona, kas ir finansiāli atbildīga par bērnu, nedzìvo tajā pašā valstī, kurā dzīvo bērns, dalībvalstis sekmē pievienošanos starptautiskiem līgumiem vai šādu līgumu noslēgšanu, kā arī veic citus piemērotus pasākumus." [1]

Lai īstenotu Bērnu tiesību konvencijas pirmās dal̦as 27. pantā noteikto, Europa 2020 stratēgijiā viens no mērķiem ir panākt nabadzībā dzīvojošo un sociāli atstumto cilvēku skaita samazināšanos. Šis uzdevums attiecināms arī uz bērnu tiesību jomu, un tas ĩstenojams, stiprinot ǵimenes politiku un sniedzot atbalstu bērnu labklājības celšanai. Mērḳa sasniegšanai tiek izveidota trīs pīlāru sistēma, kas ietver atbalsta sniegšanu giimenēm, pakalpojumu saṇemšanu un bērnu līdzdalību ar viņiem saistītos procesos. Tādējādi ES dalībvalstīm ieteikts veicināt vienotu resursu pieejamību visām ğimenēm, radot vispārēju pabalstu un ienākumu atbalstu no pašvaldībām, jo īpaši pievēršoties augsta riska gimenēm. [24]

Tiesības uz atbilstošu dzìves līmeni un sociālo nodrošinājumu ir nostiprinātas ES tiesību sistēmā, kurā tiek atbalstīta nediskriminējoša piekḷuve bērnu pabalstiem. Šāda pieeja ir nostiprināta ES Pamattiesību hartas 34. panta pirmajā dạ̦ā [5].

Izlases kārtībā analizējot ārvalstu tiesisko regulējumu saistībā ar bērnu materiālo nodrošinājumu, novērojama tendence, ka tiesību aktos arvien biežāk tiek ietverti ne tikai vispārīgi principi bērna materiālā nodrošinājuma noteikšanai, bet tiek izstrādāta un tiesību aktā ietverta arī bērna materiālā nodrošinājuma noteikšanas metodika (tas redzams, izvērtējot esošo tiesību aktu piemērošanas praksi un konstatētās problēmas). Rodžera Bērda (Roger Bird) un Deivida Berovsa (David Burrows) veiktajā Apvienotās Karalistes bērnu uzturēšanas tiesiskā regulējuma izmaiṇu analīzē [21, 31-53] uzsvērtas būtiskas izmaiṇas, kuras saistītas ar bērna uzturēšanas izmaksu noteikšanas metodiku un piemēroto aprēķinu formulu, kuru lietojot būtiski tiek palielināts aprēḳinā iekḷaujamo izdevumu pozịiju skaits. Bērna materiālā nodrošinājuma aprēḳināšanas problemātikai pievēršas arī Kirstens Šeive (Kirsten Scheiwe) un Marija Versiga (Maria Wersig), kas analizē bērna uzturēšanas izmaksu aspektu un papildus klasiskajām pozīcijām akcentē arī bērna aprūpes un laika nodrošināšanu kā ieguldījumu pašu par sevi [39, 31-48].

Saistībā ar ārvalstu tiesiskā regulējuma izvērtējumu jāizceḷ arī G̣edimina Sagata (Gediminas Sagatys) veiktais Igaunijas, Latvijas un Lietuvas bērnu uzturēšanas tiesiskā regulējuma salīdzinājums, kurā var identificēt būtiskas regulējuma atšķirības, tostarp jautājumā par bērna materiālā nodrošinājuma minimālā lieluma noteikšanu (angḷu val. minimum amount of child maintenance). Lietuvā šis jautājums atsevišḳi netiek regulēts, bet tiek noteikts katrā gadījumā individuāli, turpretī Igaunijā ikmēneša bērna uzturēšanas 
Sanita Vanaga. Bērnu tiesības uz materiālo nodrošinājumu:

tiesiskais regulējums un piedziṇas problemātika

maksājums nedrīkst būt mazāks par pusi no valstī noteiktās minimālās algas, vienlaikus paredzot tiesības ar tiesas lēmumu atsevišḳos gadījumos noteikt arī mazāku maksājumu. G̣edimins Sagats akcentē, ka, par spīti vēsturiski pastāvējušajam ilggadīgi vienotajam bērnu uzturēšanas tiesiskajam regulējumam (padomju tiesību sistēmā) un līdzīgam sociāli kulturālajam fonam, Baltijas valstu bērnu uzturēšanas tiesiskajā regulējumā ir būtiskas atšķirības, kas skaidrojamas gan ar vēlmi balstìt tiesisko sistēmu uz vēsturisko valsts tiesību avotu pārn,emšanu, gan ar valstu atšḳirīgi īstenoto sociālo politiku, kas nosaka valsts sociālā atbalsta apjomu atsevišķām personu grupām [22, 311-326].

Bērnu tiesību konvencijas 27. pantā nav paredzēta atškíin̄ga attieksme pret bērnu materiālo nodrošinājumu, tomēr šã tiesību akta 3. pantā uzsvērts, ka visām darbībām, kas tiek veiktas saistībā ar bērnu, jābūt vērstām uz bērna interešu vislabāko nodrošināšanu neatkarīgi no tā, vai tās veic privātpersonas vai valsts un pašvaldību institūcijas, tiesas, administratīvās vai likumdošanas institūcijas, primāri jāraugās, lai tiktu nodrošinātas bērnu tiesības [1].

Tomēr vairāki nacionālie tiesību akti faktiski diskriminē bērnu tiesības saṇemt materiālo nodrošinājumu - tas saistīts ar bērnam noteikto juridisko statusu -, un valsts un pašvaldības koncepcija, sniedzot bērnam materiālo atbalstu dažādās aprūpes formās, atšḳiras un nav viennozīmīga. Attiecībā uz bērnu, kas atrodas vecāku aprūpē, ja rodas strīds par bērnam nepieciešamo uzturlīdzekḷu apjomu materiālo vajadzību nodrošināšanai, vecāks ir tiesīgs civilprocesuālā kārtībā vērsties tiesā par uzturlīdzekḷu piedziṇu no tā vecāka, kurš bērnu materiāli nenodrošina. Šāda tiesība un pienākums ir saglabāta arī bērna likumiskajiem aizbildṇiem, bet likumiski šāda rīcība nav paredzēta audžug̣imenē un ilgstošas sociālās aprūpes un sociālās rehabilitācijas institūcijā ievietoto bērnu likumiskajiem pārstāvjiem.

Valsts un pašvaldỉba, pamatojoties uz Valsts sociālo pabalstu likuma 10. un 11. pantu [17] un 22.12.2009. Ministru kabineta noteikumu Nr. 1600 "Kārtība, kādā piešķir un izmaksā atlīdzību par aizbildṇa pienākumu pildīšanu” 2. punktu [6], 22.12.2009. Ministru kabineta noteikumu Nr. 1643 "Kārtība, kādā pieškir un izmaksā pabalstu aizbildnim par bērna uzturēšanu” 2. punktu [8], 22.12.2009. Ministru kabineta noteikumiem Nr. 1549 "Kārtība, kādā pieškir un izmaksā atlīdzību par audžuǵimenes pienākumu pildīšanu" [7], kā arī katras Latvijas Republikas pašvaldību saistošajos noteikumos noteikto par izmaksājamo pabalstu veidu un apmēru bērna uzturam, kuri ievietoti ārpusǵimenes aprūpē aizbildnībā un audžuǵimenē, garantē atšķirīgu pabalstu izmaksas kārtību ārpusǵimenes aprūpē ievietoto bērnu materiālo vajadzību nodrošināšanai un atlīdzību par aizbildṇu un audžuğimenes pienākumu pildišanu.

Savukārt bērnam, kurš palicis bez vecāku gādības un ievietots bērnu aprūpes institūcijā, pakalpojumu saṇemšanas kārtība, ar to saprotot bērna uzturēšanos institūcijā kārtîbu, noteikta 21.04.2008. Ministru kabineta noteikumos Nr. 288 "Sociālo pakalpojumu un sociālās palīdzības saṇemšanas kārtība", kuros paredzèta noteikta formula, kas satur kritērijus, pēc kuriem tiek aprēḳinātas izmaksas par bērna uzturēšanos Valsts ilgstošas sociālās aprūpes un sociālās rehabilitācijas institūcijā [15], bet likuma "Par pašvaldībām" 
21. panta astotajā punktā noteikta pašvaldības kompetence bērnu aprūpes institūciju izveidē tās administratīvajā teritorijā, kuras izveides un uzturēšanas izdevumi tiek segti no pašvaldības budžeta [14].

Šajos tiesību aktos, kā arī vēl daudzās citās speciālajās tiesību normās ir noteikti vairāki pabalstu veidi bērnu materiālo vajadzību nodrošināšanai, tomēr jāuzsver, ka šajās tiesību normās paredzēta atšḳirīga valsts un pašvaldību attieksme un palīdzības sniegšanas kārtība, ñemot vērā bērna juridisko statusu, lai gan neatkarīgi no bērna juridiskā statusa viņa materiālo vajadzību kopums ir nemainīgs, savukārt bērna dabisko, likumisko un faktisko aprūpētāju pienākumi nav atškiringi, bet valsts un pašvaldības atbalsta koncepcija to ignorē.

\section{Uzturlīdzekḷu apmēra pierādīšanas un piedziṇas problemātika tiesvedības procesā}

Saskaṇā ar Civilprocesa likuma 127. panta otro dalı nepilngadīga bērna interesēs viṇa likumiskais pārstāvis ir tiesīgs celt prasību tiesā par uzturlīdzekḷ piedziṇu bērna uzturam [4]. Tomēr jāatzīmē, ka bieži vien pieteicējam trūkst zināšanu prasības pieteikuma sagatavošanai un nepieciešamo dokumentu un pierādijjumu iesniegšanai un tas būtiski sarežğì uzturlīdzekḷu apmēra pierādǐšanu pašam prasitājam. Lai gan 29.05.2018. Ministru kabineta noteikumu Nr. 305 "Noteikumi par vienkāršotajā procedūrā izmantojamām veidlapām" 2 . pielikumā ir veidlapa, kuras aizpildī̌̌ana prasītājam vienkāršo prasības pieteikuma sagatavošanu [12], tomēr, cel̦ot prasību tiesā par lielāku uzturlīdzekḷu apmēra piedziṇu nekā valstī noteikto minimālo uzturlīdzekḷu apmēru, prasītājam tiesai jāiesniedz prasību pamatojoši un pierādoši dokumenti, vienlaikus n̦emot vērā, ka tiem jābūt ar nozīmi lietas izskatīšanā [4].

Latvijas Universitātes docente, individuāli praktizējoša zvērināta advokāte Daina Ose ir norādỉjusi, ka ḷoti būtiska nozīme civilprocesā ir pierādǐšanas institūtam, kur tiek noskaidrota strīda būtība un pierādāmo faktu pastāvēšana, taču Latvijā šā institūta pētniecỉba nav attīstìta, tādēḷ līdz šim pētỉjumos nav izdalìti pierādǐšanas institūta principi no kopējiem civilprocesa principiem [35].

Tiesību zinātṇu doktors, Krievijas Federācijas profesors, zinātnieks un Civilprocesa departamenta vadītājs Mihails Treušn,ikovs (Михаил Константинович Треушников) ir norādījis, ka tiesību ideja, kura nav nostiprināta tiesību normās, pastāv tikai kā tiesību doktrīna [42].

Savukārt Aivars Līcis zinātniskajā literatūrā norādījis, ka jebkura pamatideja uzskatāma par principu, ja tā noteiktā kārtībā nostiprināta normatīvajos aktos [33, 127].

Profesors, civilprocesu pētnieks, Dr. iur. Vladimirs Bukovskis ir uzsvēris, ka sacīkstes principam civilprocesā ir savas pozitivās îpašỉbas, kuras saistāmas tieši ar pušu spējām norādīt uz tiem apstākḷiem un pierādījumiem, kuri ir vajadzīgi un nozīmīgi lietas izskatîšanā, jo tieši puses ir tās, kuras savu lietu pārzina vislabāk un zina, kur pierādījumi ir iegūstami $[23,235]$. 
Sanita Vanaga. Bērnu tiesības uz materiālo nodrošinājumu:

tiesiskais regulējums un piedziṇas problemātika

Sacīkstes princips civilprocesā kā kopīgs civilprocesa princips nav absolūts, tas atkarīgs no lietas dalībnieku zināšanām un spējām pierādìt savu taisnību, savukārt tiesnesim, līdzdarbojoties tiesas spriešanas interesēs, ir iespējams noskaidrot patiesību.

Latvijas Republikas Augstākās tiesas Senāta Civillietu departamenta tiesu prakses vispārinājumā ir pausta atziņa, ka, nosakot piedzenamo uzturlīdzekḷ apmēru bērnam, jānem vērā tās puses ienākumi, no kuras tiek piedzìti uzturlīdzekḷi, šim nolūkam jānoskaidro puses ienākumu apjoms - vai tas ir pietiekams, lai nodrošinātu pieprasīto uzturlīdzekḷu lielumu. Pierādījumi, kuri apliecina personas labklājības līmeni, piemēram, ìpašumā esošie kustamie un nekustamie ipašumi, nevar tikt atzīti par vienīgo apstākli, uz kuru balstìties lietas izspriešanā, papildus neṇemot vērā personas ienākumus, bet jāṇem vērā arī personas spēja savus ienākumus papildināt, tātad nopelnīt, kas ir saistìta ar personas vecumu, izglìtību, darba pieredzi, veselības stāvokli u. c. kritērijiem. Tiesas ieskatā par pamatu jāṇem vērā jēdziena "bērna uzturēšana" kritēriji, kuri iekḷauti Civillikuma 177. pantā. [38]

Rīgas apgabaltiesas Civillietu tiesas kolēgijas tiesnesis Valdis Vazdikis uzsver, ka būtiski ir norādīt precīzas bērnam nepieciešamo materiālo vajadzību pozīcijas gada griezumā, sākot no bērna uztura līdz kredīta maksājumiem, kas saistīti ar bērna vajadzību nodrošināšanu, t. sk. mājokḷa un komunālo maksājumu izdevumus, izdalot bērna daḷu, kam par pierādījumu der izdevumu čeki un kvïtis [20].

Lai gan uzturlīdzekḷu piedziṇas lietās tiek ievērots sacīkstes princips, galvenā uzturlīdzekḷ apmēra pierādīšanas nasta gulstas tieši uz prasības iesniedzēju, bet atbildētājam nav pienākums sniegt pilnīgi visas un atklātas ziṇas par viṇa materiālo stāvokli un spējām bērnu uzturēt, turklāt atbildētājam saglabājas tiesības celt iebildumus pret prasītāja iesniegtajiem pierādījumiem un pozīcijām, kas norādītas kā saistītas ar bērna materiālajām vajadzībām. Taču praksē uzturlīdzekḷu piedziṇas lietās netiek ìstenotas Bērnu tiesību aizsardzības likuma 13. panta [2] un Bērnu tiesību konvencijas 12. panta [1] tiesību normas, kurās paredzētas bērna tiesības tikt uzklausītam. Neievērojot šos tiesiskos regulējumus, ne tikai tiek būtiski aizskartas bērna tiesības, bet arī netiek ņemts vērā, ka bērna viedoklim tiesvedības procesā var tikt piešḳirta pierādījumu nozīme.

Minēto apstiprina Bukarestes Policijas akadēmijas asociētās profesores Valērijas Georgijas (Valeria Gheorghiu) viedoklis, kurš balstìts uz zinātnisku pētijumu. Profesore norāda, ka jurisprudencei jābūt vienotai, tā abiem vecākiem uzliek pienākumu rūpēties par bērnu neatkarīgi no tā, pie kura vecāka bērnam ir noteikta dzìvesvieta, tiesību normām jābūt skaidri izteiktām un vērstām uz bērna interešu aizsardzību [27].

Eiropas līmenī bērnam draudzīga un taisnīga tiesu sistēma būs tikai tad, kad visu valstu tiesību akti būs saskaṇoti ar Bērnu tiesību konvencijā noteikto bērnu tiesību izmantošanu, ar Eiropas Sociālo lietu komiteju un Eiropas sociālo hartu, kā arī tiks pārskatīta Eiropas Cilvēktiesību konvencija. Tiesiskuma bērna interesēs mērḳis ir aizsargāt bērnu intereses ES tiesvedības procesos, tādēḷ būtiski ir ievērot minētajos tiesību aktos noteiktās bērna tiesības tikt uzklausìtam kā pilnvērtīgam lietas dalïbniekam un dot iespēju bērnam brīvi izteikties [27, 271-281]. Tā kā iespēja pierādīt pilnīgi visas bērna vajadzības 
Sanita Vanaga. Bērnu tiesības uz materiālo nodrošinājumu:

tiesiskais regulējums un piedziṇas problemātika

ir ierobežota un arī atbildētājs var vēlēties slēpt savu patieso spēju bērnam nodrošināt materiālās vajadzības, civilprocesa ietvaros sacensības princips bērna tiesību un interešu ievērošanu uz pilnvērtīgu materiālo vajadzību nodrošināšanu būtiski ierobežo. Jāuzsver, ka puses nav gluži vienādās pozīcijās, iesniedzot pierādījumus, jo atbildētāja puse bieži nav ieinteresēta uzrādīt savu patieso materiālo stāvokli, bet prasîtājam ir ierobežotas iespējas pierādìt, ka atbildētājs slēpj savus patiesos ienākumus, piemēram, kustamo un nekustamo īpašumu reǵistrējot uz citu personu vārda. Tiesiskajā regulējumā gan ir paredzētas sankcijas par nepatiesu ziṇu sniegšanu, tomēr tās nenodrošina atbildētāja saukšanu pie atbildības, ja zinas netiek atklātas.

Uzturlīdzekḷu piedziṇas iespējamībai tiesvedības procesā būtiski ir ievērot lietas dalïbnieku ierašanos uz tiesas sēdi, par kuru lietas dalībniekiem tiek paziṇots Civilprocesa likuma 54. pantā noteiktajā kārtībā [4]. Latvijas Republikas Augstākās tiesas Civillietu departamenta 2014. gada 28. februāra spriedumā Nr. SKC-1410/2014 tiesa paudusi atziṇu, ka, nosūtot adresātam pavēsti ierakstītā sūtỉjumā, darbojas prezumpcija par tiesas izpildìto pienākumu paziṇot lietas dalībniekiem lietas izskatî̌anas laiku un vietu [19]. Latvijas Republikas Augstākās tiesas Administratīvo lietu departamenta 2015. gada 25. jūnija spriedumā lietā Nr. SKA-848/2015 pausta atzinna, ka adresātam ir pienākums līdzdarboties dokumentu apritē, tātad adresātam jārūpējas par faktisku sasniedzamību norādītajā adresē, jāuztur kārtībā elektroniskās pasta kastītes vai citi likumā noteiktie dokumentu paziṇošanas veidi. Pienākumu neizpildīšanas gadījumā adresāts var izvairīties no dokumentu faktiskas saṇemšanas, tomēr tas neatbrīvo no dokumentu saṇemšanas tiesiskā nozīmē [18]. Izvairī̌sanās no ierašanās uz tiesas sēdi rada savlaicīgas un bērnu tiesību ievērošanai atbilstošas procesa virzības problēmas, kaut arī nevienā tiesiskajā regulējumā nav paredzēts, cik ilgā laikā jāizskata noteikta lieta.

Lietas izskatīšanu paildzina arī tiesas sprieduma pārsūdzēšana nākamajā tiesu instancē, tādēḷ procesa ierosināšanas termiṇi tiek noteikti atkārtoti. Tas būtiski paildzina lietas izskatǐšanu līdz laikam, kad galīgais spriedums stājas spēkā. Savukārt tiesas sprieduma stāšanās spēkā vēl nenozīmē tā labprātīgu izpildi pilnā apjomā [4].

Luublinas Jāṇa Pāvila II Katoḷu Universitātes politikas zinātṇu doktore, profesore Elžbeta Ščota (Elżbieta Szczot) ir uzsvērusi, ka bērna tiesības ir neatņemama cilvēktiesību sastāvdal̦a. Valsts savā darbībā nevar bērna tiesības atcelt, mainīt, ierobežot vai apturēt, valsts pienākums ir dažādu uzdevumu veikšana, lai aizsargātu gimenes, it īpaši bērna, tiesības. Profesore arī norādijjusi, ka valsts ir atbildības subjekts, kas atbilst ANO noteiktajām gimenes tiesībām. Ar to jāsaprot, ka valsts ar savu rīcību, nosakot konkrētu darbïbu veikšanu un mērḳi nesasniedzot, ierobežo ğimenes, tostarp bērna, tiesības. Valstij ir pienākums veikt visus pasākumus, lai īstenotu bērna tiesības, ar to saprotot, ka šie pasākumi ietver valsts juridisku, politisku un ekonomisku rīcību [40, 277-294].

Dispozīcija uzturlīdzekḷ u piedziṇas lietās tiesvedības procesā veidojas, kad bērnam tiek noteikta ārpusğimenes aprūpe audžuğimenē vai ilgstošas sociālās aprūpes un sociālās rehabilitācijas institūcijā. Jānnem vērā, ka šādā situācijā bērnu neaprūpē neviens no vecākiem, bērnam var būt nenokārtots paternitātes jautājums, kā arī vecāku spēja sniegt 
bērnam materiālo nodrošinājumu un uzturlīdzekḷus atbilstoši bērna materiālajām vajadzībām ir nesalīdzināmi mazāka nekā tad, ja bērns aug vecāku aizgādībā. N̦emot vērā, ka 18.03.2014. Ministru kabineta noteikumos Nr. 142 "Noteikumi par ārpusğimenes aprūpes pakalpojumu samaksas kārtību un apmēru" noteikta kārtība un apmērs, kurā tiek noteikta samaksa par bērna uzturēšanos audžuğimenē vai bērnu aprūpes institūcijā [10], tiesiskais regulējums liedz valsts un pašvaldību institūcijām tiesvedības procesā no vecākiem piedzît uzturlīdzekḷus ārpusğimenes aprūpē esoša bērna uzturam vairāk nekā valstī noteiktā minimālā uzturlīdzekḷu apmērā.

Šāda kārtība skaidrojama ar minētā tiesību akta tiesisko regulējumu, ar kuru tiek vecākam uzlikts pienākums katru mēnesi maksāt par bērnam sniegtajiem pakalpojumiem noteikto minimālo uzturlīdzekḷu lielumu. Lai gan šā tiesību akta normās noteikta valsts institūcijas un pašvaldības rīcība, lai parādnieks piespiedu kārtā samaksātu uzturlīdzekḷus, neceḷot prasību tiesā pret parādnieku par viṇa bērnam sniegtajiem ārpusǵimenes aprūpes pakalpojumiem un atvieglojot procesu (attiecībā uz tā ilgumu un patērētajiem resursiem, ja lietu nodotu parāda piedziṇas izpildei tiesu izpildītājam), tomēr vispārējā uzturlīdzekḷu piedziṇas tiesvedības kārtībā tiek liegta iespēja piedzìt no vecāka uzturlīdzekḷu summas starpību, kas izveidojusies starp noteikto samaksas kārtību no vecāka un samaksāto summu no valsts institūcijas un pašvaldības budžeta.

Vestminsteras Universitātes profesore Vala Gillīza (Val Gillies) ir uzsvērusi, ka, veidojot valsts politiku, kas vērsta uz vecāku atbalstǐšanu bērnu audzināšanas procesos, jānodrošina virziens, kas veicina vecāku uzṇemšanos pildìt savus pienākumus, nevis jāatstāj tas valsts pārzinnā. Valsts stratēǵija gímenes atbalsta politikā jāveido tā, lai vecākam nerastos pārliecība, ka valsts viṇa vietā materiāli par bērnu parūpēsies [28, 70-90].

Latvijas pašreizējā tiesiskajā regulējumā paredzēta valsts iespēja izmaksāt uzturlīdzekḷus bērna materiālo vajadzību nodrošināšanai no Uzturlīdzekḷu garantiju fonda gadījumos, kad vecāks kādu apstākḷu dēl vai apzināti to nedara. Taču uzturlīdzekḷu parādu piedziṇas procesā izstrādātās sankcijas pret uzturlīdzekḷu parādnieku nav pilnīgas, jo tās nenodrošina valsts un pašvaldību izmaksāto uzturlīdzekḷu atgūšanu.

\section{Secinājumi}

1. Uzturlīdzekḷu bērna materiālo vajadzību nodrošināšanai definējums ir tikai deklaratīva norma, kura netiek saistìta ar tās ieviešanu praksē. Šì brī̌za tiesiskajā regulējumā uzturlīdzekḷu definīcija nav izstrādāta un iekḷauta.

2. Praksē uzturlīdzekḷu piedziṇas lietās tiesvedības procesā bērns netiek uzklausīts un viņa viedoklis netiek noskaidrots, kas būtiski ierobežo bērna tiesības atbilstoši savam vecumam un brieduma pakāpei sniegt savu vērtējumu attiecībā uz viña materiālo vajadzību nodrošinājumu.

3. Bērna tiesību ierobežošana, neuzklausot un nenoskaidrojot bērna viedokli uzturlīdzekḷu piedziṇas lietās, skar arī tiesvedības procesā izskatāmās uzturlīdzekḷu piedziṇas lietas rezultātu, jo bērna liecību par viņam ikdienā nodrošinātajām materiālajām vajadzībām var pielīdzināt pierādījumiem. 
4. Valsts un pašvaldības materiālā atbalsta koncepcija netiek attiecināta uz bērna izaudzināšanu par pilnvērtīgu sabiedrības locekli, jo valsts un pašvaldības finansiālais atbalsts ir sadrumstalots un nesamērojams ar bērna ikdienas vajadzību nodrošināšanu.

5. Prasītājam uzturlīdzekḷ u piedziņas lietās ir jāpierāda pašsaprotamas bērna vajadzības, kuras pat nav iespējams visos sīkumos uzskaitìt un pierādīt, turpretim atbildētājam ir pienākums tikai pierādìt savus iebildumus, uzskatot, ka prasītājs piedzìto uzturlīdzekḷu apmēru, kas ir lielāks par MK noteikumos Nr. 37 noteikto minimālo uzturlīdzekḷu apmēru, , iespējams, izlietos savām vai citām vajadzībām, tos nenovirzot bērna materiālo vajadzību nodrošināšanai.

6. Šì brī̌za tiesiskajā regulējumā paredzēts, ka valsts institūcijām un pašvaldībām nav tiesiska instrumenta, ar kuru civilprocesuālā kārtībā piedzìt no vecākiem izmaksāto uzturlīdzekḷ u summu par bērnu, kurš ievietots ārpusǵimenes aprūpē. Turklāt no vecākiem nevar piedzît bērna materiālo vajadzību nodrošināšanai izmaksāto uzturlīdzekḷu summu, kas pārsniedz MK noteikumos Nr. 37 noteikto minimālo uzturlīdzekḷu apmēru.

\section{Rights of Children to Material Provision: Legal Framework and Problem of Recovery}

\section{Abstract}

Rights of children to a material provision is an essential and integral part of human rights, which are stipulated in national and international legal acts. This article analyses the essence and the number of rights of children to a material provision, depending on their legal status, and explains legal importance of a child's legal status.

The article also reflects on support, provided by governmental and local authorities for children with a different legal status, as well as on problems faced in legal proceedings that relate to proof of the required maintenance allowance and recovery of maintenance.

Keywords: rights of children, material provision, maintenance, allowance.

\section{Avoti un literatūra}

Tiesību akti

1. ANO Bērnu tiesību konvencija: starptautisks dokuments: pieṇemta 20.11.1989. un stājās spēkā 02.09.1990. Latvijas Vēstnesis. 237(5297), 28.11.2014. Iegūts no: https://likumi.lv/ta/lv/starptautiskie-ligumi/id/1150 [sk. 15.03.2019.]. 
Sanita Vanaga. Bērnu tiesības uz materiālo nodrošinājumu: tiesiskais regulējums un piedziṇas problemātika

2. Bērnu tiesību aizsardzības likums: Latvijas Republikas likums: pieṇemts 19.06.1998. un stājies spēkā 22.07.1998. Latvijas Vēstnesis. 199/200(1260/1261), 08.07.1998. Iegūts no: https://likumi. lv/doc.php?id=49096 [sk. 15.03.2019.].

3. Civillikums: Latvijas Republikas likums: pieṇemts 28.01.1937. un stājies spēkā 01.09.1992. Valdïbas Vēstnesis. 41, 20.02.1937. Iegūts no: https://likumi.lv/doc.php?id=225418 [sk.15.03.2019.].

4. Civilprocesa likums: Latvijas Republikas likums: pieṇemts 14.10.1998. un stājies spēkā 01.03.1999. Latvijas Vēstnesis. 326/330(1387/1391), 03.11.1998. Iegūts no: https://likumi.lv/doc.php?id=50500 [sk.15.03.2019.].

5. Eiropas Savienības pamattiesību Harta: starptautisks līgums. Oficiālais Vēstnesis. C 326/391, 26.10.2012.

6. Kārtība, kādā piešḳir un izmaksā atlīdzību par aizbildṇa pienākumu pildī̌̌anu: Latvijas Republikas Ministru kabineta noteikumi Nr. 1600: pieṇemti 22.12.2009. un stājās spēkā 01.01.2010. Latvijas Vēstnesis. 204(4190), 29.12.2009. Iegūts no: https:/likumi.lv/doc.php?id=202845 [sk. 15.03.2019.].

7. Kārtība, kādā piešḳir un izmaksā atlīdzību par audžuǵimenes pienākumu pildīšanu: Latvijas Republikas Ministru kabineta noteikumi Nr. 1549: pieñemti 22.12.2009. un stājās spēkā 01.01.2010. Latvijas Vēstnesis. 203(4189), 28.12.2009. Iegūts no: https://likumi.lv/doc.php?id=202717 [sk. 15.03.2019.].

8. Kārtība, kādā piešḳir un izmaksā pabalstu aizbildnim par bērna uzturēšanu: Latvijas Republikas Ministru kabineta noteikumi Nr. 1643: pieṇemti 22.12.2009. un stājās spēkā 01.01.2010. Latvijas Vēstnesis. 206(4192), 31.12.2009. Iegūts no: https://likumi.lv/doc.php?id=202947 [sk. 15.03.2019.].

9. Latvijas Republikas Satversme: Latvijas valsts likums: pieṇemta 15.02.1922. un stājās spēkā 07.11.1922. Latvijas Vēstnesis. 43, 01.07.1993. Iegūts no: https://likumi.lv/doc.php?id=57980 [sk. 15.03.2019.].

10. Noteikumi par ārpusǵimenes aprūpes pakalpojumu samaksas kārtību un apmēru: Latvijas Republikas Ministru kabineta noteikumi Nr. 142: pieṇemti 18.03.2014. un stājās spēkā 01.04.2014. Latvijas Vēstnesis. 58(5118), 21.03.2014. Iegūts no: https://likumi.lv/doc.php?id=265120 [sk. 15.03.2019.].

11. Noteikumi par minimālo uzturlīdzekḷu apmēru bērnam: Latvijas Republikas Ministru kabineta noteikumi Nr. 37: pieṇemti 15.01.2013. un stājās spēkā 18.01.2013. Latvijas Vēstnesis. 12(4818), 17.01.2013. Iegūts no: https://likumi.lv/doc.php?id=254128 [sk. 15.03.2019.].

12. Noteikumi par vienkāršotajā procedūrā izmantojamām veidlapām: Latvijas Republikas Ministru kabineta noteikumi Nr. 305: pieṇemti 29.05.2018. un stājās spēkā 01.07.2018. Latvijas Vēstnesis. 106(6192), 31.05.2018. Iegūts no: https://likumi.lv/ta/id/299326-noteikumi-par-vienkarsotajaprocedura-izmantojamam-veidlapam [sk. 15.03.2019.].

13. Par iedzīvotāju naudas ienākumu indeksācijas nodrošināšanu: Latvijas Republikas Ministru Padomes lēmums Nr. 95: pieṇemts un stājās spēkā 08.04.1991., zaudējis spēku. Ziṇotājs. 27/28, 18.07.1991. Iegūts no: https://likumi.lv/doc.php?id=67927 [sk. 15.03.2019.].

14. Par pašvaldībām: Latvijas Republikas likums: pieņemts 19.05.1994. un stājies spēkā 09.06.1994. Latvijas Vēstnesis. 61(192), 24.05.1994. Iegūts no: https://likumi.lv/doc.php?id=57255 [sk. 15.03.2019.].

15. Sociālo pakalpojumu un sociālās palīdzības saṇemšanas kārtība: Latvijas Republikas Ministru kabineta noteikumi Nr. 288: pieṇemti 21.04.2008. un stājās spēkā 24.04.2008. Latvijas Vēstnesis. 63(3847), 23.04.2008. Iegūts no: https://likumi.lv/doc.php?id=174327 [sk. 15.03.2019.]. 
16. Uzturlīdzekl̦u garantiju fonda likums: Latvijas Republikas likums: pieṇemts 01.12.2016. un stājies spēkā 01.02.2017. Latvijas Vēstnesis. 249(5821), 21.12.2016. Iegūts no: https://likumi.lv/ ta/id/287534-uzturlidzeklu-garantiju-fonda-likums [sk. 15.03.2019.].

17. Valsts sociālo pabalstu likums: Latvijas Republikas likums: pien,emts 31.10.2002. un stājies spēkā 01.01.2003. Latvijas Vēstnesis. 168(2743), 19.11.2002. Iegūts no: https://likumi.lv/doc. php?id=68483 [sk. 15.03.2019.].

\section{Tiesu prakse}

18. Latvijas Republikas Augstākās tiesas Administratīvo lietu departamenta 2015. gada 25. jūnija spriedums lietā Nr. SKA-848/2015. Iegūts no: http://31.24.192.35/downloadlawfile/4345 [sk. 15.12.2018.].

19. Latvijas Republikas Augstākās tiesas Civillietu departamenta 2014. gada 28. februāra spriedums lietā Nr. SKC-1410/2014. Iegūts no: https://www.tiesas.lv/nolemumi/pdf/148735.pdf [sk. 15.12.2018.].

\section{Literatūra}

20. Bērnam uzturlīdzekḷi ir vajadzīgi pastāvīgi, paredzami un regulāri. 2017. $L V$ [portāls]. Iegūts no: https://lvportals.lv/tiesas/291232-bernam-uzturlidzekli-ir-vajadzigi-pastavigi-paredzamiun-regulari-2017 [sk. 12.02. 2019.].

21. Bird, R., Burrows, D. 2009. Child Maintenance: The New Law. Family Law. UK, Bristol: Jordan Publishing Limited.

22. Boele-Woelki, K., Miles, J., Scherpe, J. M. 2011. The future of Family Property in Europe. UK, Intersentia Cambridge: Trinity House.

23. Bukovskis, V. 1933. Civīlprocesa mācības grāmata. Rìga.

24. Child Poverty and Wellbeing in Europe. 2012. Iegūts no: https://www.esn-eu.org/sites/default/ files/publications/ESN_position_paper_on_Child_Poverty_and_Wellbeing.pdf [sk. 12.12.2018.].

25. Cilvēktiesības pasaulē un Latvijā. 2000. Aut. kol. S. Garsvāne, A. Kamenska, I. Leimane u. c. Rīga: JUMI.

26. Ferreira, N. 2011. The Harmonisation of Private Law in Europe and Children's Tort Liability: A Case of Fundamental and Children's Rights Mainstreaming. International Journal of Children's Rights. Vol. 19, 3, 571-594.

27. Gheorghiu, V. 2016. Examination of Judicial Practice on the Exercise of Parental Authority by a Single Parent. Tribuna Juridică. Vol. 6, 2, 271-281.

28. Gillies, V. 2005. Meeting Parents' Needs? Discourses of 'Support' and 'Inclusion' in Family Policy. Critical Social Policy. Vol. 25, 1, 70-90.

29. Koncepcijas projekts "Par minimālā ienākuma līmeṇa noteikšanu”. 2014. Latvijas Republikas Labklājības ministrija. Iegūts no: http://tap.mk.gov.lv/doc/2015_01/LMkonc_201014.2324.docx [sk.13.11.2018.].

30. Krastiņš, O. 1997. Kas ir mūsu iztikas minimuma preču un pakalpojumu grozā? Latvijas Vēstnesis. 98, 17.04.1997. Iegūts no: https://www.vestnesis.lv/ta/id/43036 [sk. 13.11.2018.].

31. Krauklis, V., Ūḳis, G., Krauklis, J. 1999. Likumdošanas aktu terminu vārdnīca. Rīga: Senders R. 32. Latviešu-anglı u, anglı-latviešu juridisko terminu vārdnīca. 2002. Rīga: Kamene.

33. Līcis, A. 2003. Prasības tiesvedība un pierādījumi. Rīga: Tiesu nama agentūra. 
34. Likumdevējs nav ierobežojis nosakāmo uzturlīdzekḷu apmēru. 2018. $L V$ [portāls]. Iegūts no: https://lvportals.lv/e-konsultacijas/15704-likumdevejs-nav-ierobezojis-nosakamo-uzturlidzekluapmeru-2018 [sk. 27.11.2018.].

35. Ose, D. Pierādīšanas institūta principi civilprocesā. Daugavpils Universitāte. Iegūts no: https:// dukonference.lv/files/proceedings_of_conf/53konf/tiesibas/Ose.pdf [04.04.2018.].

36. Pārskats par bāriṇtiesu darbu 2017. gadā: kopsavilkums. 2017. Latvijas Republikas Bērnu tiesību aizsardzības inspekcija. Iegūts no: http://www.bti.gov.lv/in_site/tools/download.php?file=files/ text/bt.stat_2017.pdf [sk. 09.10.2018.].

37. Pārskats par bāriṇtiesu darbu: kopsavilkums. Latvijas Republikas Bērnu tiesību aizsardzības inspekcija. Iegūts no: http://www.bti.gov.lv/lat/barintiesas/statistika/ [sk. 28.02.2019.].

38. Par tiesu praksi strīdu izskatǐšanā par aizgādības (kopīgas, atsevišḳas, ikdienas) un saskarsmes tiesībām un uzturlīdzekḷiem bērnam. 2012. Latvijas Republikas Augstākā tiesa. Iegūts no: http:// at.gov.lv/files/uploads/files/docs/petijumi/aizgadiba\%20uzturl\%20saskarsme_petijums_2012. doc [sk. 26.02.2019.].

39. Scheiwe, K., Wersig, M. 2011. Cash und Care - Kindesunterhaltsrecht und Geschlechter(un) gleichheit. Deutschland: V\&R Unipress in Göttingen.

40. Szczot, E. 2015. The Right of the Child to Decent Social Conditions and Education. Ecumeny and Law. Vol. 3, 3, 277-294.

41. Viena iedzìvotāja pilna iztikas minimuma preču un pakalpojumu groza vērtība. Centrālās statistikas pārvaldes datubāzes. Iegūts no: https://data1.csb.gov.lv/pxweb/lv/sociala/sociala__ mb_ienakumi/IIG010.px/table/tableViewLayout1/?rxid=226144ec-9f27-4a7f-be77-f5b3f4742f8b [sk. 13.11.2018.].

42. ГражАанский процесс. 2007. Bloglaw.Ru Iegūts no: http://www.bloglaw.ru/wp-content/2010/01/ treushnikov_1.pdf [sk. 06.12.2018.]. 